\title{
Overhaul recommended for gene-therapy review
}

\section{US Institute of Medicine says the Recombinant DNA Advisory Committee's activities should be scaled back.}

\section{Erika Check Hayden}

05 December 2013

The US National Institutes of Health (NIH) should refocus its oversight of genetransfer research, the US Institute of Medicine (IOM) says in a report released today.

The analysis concludes that the NIH's Recombinant DNA Advisory Committee, or RAC, should no longer review most gene-therapy research. But there are some areas that it says the RAC should still oversee - such as studies that involve new gene-transfer vectors or that pose particular safety worries. The panel adds that the $\mathrm{NIH}$ should also give the committee a broader remit to review any kind of emerging research in humans that deserves special scrutiny because it raises safety or ethical issues.

The report is a point in favour of researchers who requested the review, saying that gene therapy should no longer be singled out for special public scrutiny. It is now up to the $\mathrm{NIH}$ to decide what to do.

The agency will take a close look at the findings, NIH Director Francis Collins said in a statement today. "The field has evolved greatly over the past two decades, and an examination of ways to optimize how we foster science and safety in this field is timely indeed," Collins added.

The report won praise from the American Society of Gene \& Cell Therapy (ASGCT) in Milwaukee, Wisconsin. "The outcome of the review is clearly thoughtful and

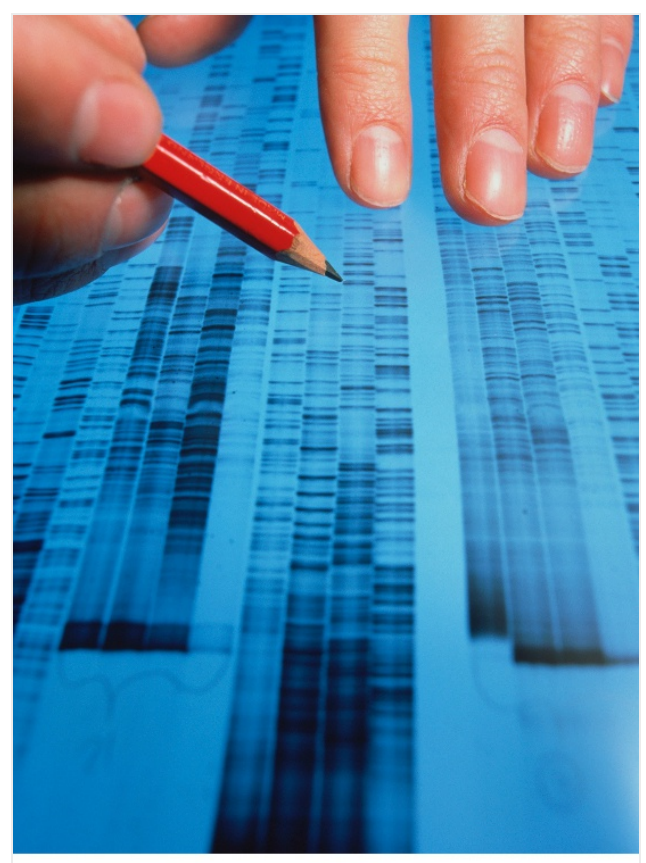

SINCLAIR STAMMERS/SCIENCE PHOTO LIBRARY

US gene-therapy research has been subject to special review since 1974. balanced, taking into account a broad range of opinions from a diverse group of stakeholders," it said in a statement. "The Society looks forward to the National Institutes of Health ( $\mathrm{NIH}$ ) Director's review of and decisions based on the IOM's findings."

\section{Reduced oversight}

The RAC was created in 1974 to provide public oversight of what was then a new form of scientific activity. Until 1995, it had the authority to approve proposed gene-transfer research. Now, the US Food and Drug Administration formally approves gene-therapy trials in humans, and institutional review boards and biosafety committees also review the work.

All individual gene-therapy trial plans must still be submitted to the RAC, which selects about $20 \%$ for in-depth scrutiny at public meetings. It can recommend changes to investigators' plans in addition to those asked for by other reviewing bodies. That has led researchers to bridle at what they call many layers of duplicative review.

In March last year, the ASGCT recommended that the RAC cease reviewing individual trial plans and instead focus on convening public discussion around new ethical or safety issues in the field. The NIH responded by commissioning the IOM review; the process began this April.

\section{Middle path}

Sharon Terry, president of the non-profit Genetic Alliance in Washington DC and a member of the IOM panel, says that the panel "slid way towards the side of disbanding the RAC" because researchers have now acquired decades of safety data on gene transfer, and because the current oversight structure has become a burden. "We heard across the board that duplicity and different kinds of filings that scientists are responsible for are slowing down trials that should go forward."

But the panel stopped short of recommending that the RAC be shut down, because its oversight may still be needed in exceptional circumstances, she adds. "We can't shut down a body that still has a function in certain cases, and may in fact also be a model for 
other kinds of science that should have the same kind of scrutiny and public discussion that RAC has offered."

The report says that areas such as nanotechnology, synthetic biology and some aspects of neurobiology might benefit from a RAC-like review.

The RAC has not prevented mistakes such as the death of 18-year-old Jesse Gelsinger during a gene-transfer trial in 1999. But that tragic event led to revisions in some clinical-trial procedures, such as introducing a requirement that investigators report all adverse events during a trial. Since then, the report argues, public perception of the field has improved thanks to the growing evidence that it can help patients with disorders such as severe combined immunodeficiency syndrome.

The panel concludes that "not all of gene transfer research is still considered an entirely new scientific enterprise or novel technology and therefore not all protocols warrant special/public oversight by the RAC".

Nature | doi:10.1038/nature.2013.14313 